\title{
Perakitan dan perbaikan komputer untuk meningkatan kualitas remaja di Desa Pandau Jaya Kecamatan Siak Hulu Kabupaten Kampar
}

\author{
Alfirman*, Sukamto, Gita Sastria, dan Zaiful Bahri \\ Universitas Riau \\ * alfirman@lecturer.unri.ac.id
}

\begin{abstract}
Abstrak. Tujuan yang ingin dicapai dalam kegiatan pengabdian kepada masyarakat ini ialah, agar masyarakat peserta dapat: 1). Memiliki pengetahuan tentang bagaimana cara perakitan dasar komputer, 2). Memiliki pengetahuan tentang bagaimana melakukan installasi sistem operasi windows dan beserta program-program aplikasinya, 3). Memiliki pengetahuan tentang cara memperbaiki / trobleshooting pada komputer hardware maupun software. Pengabdian masyarakat ini dilakukan berdasarkan pengamatan kami, bahwa di Desa Pandau Jaya Kecamatan Siak Hulu 80\% masyarakatnya tidak mempunyai pengetahuan mengenai perakitan dan maintenance pada komputer PC (Personal Computer) maupun laptop. Dengan berkembangnya teknologi khususnya komputer yang semakin luas, sehingga memberi peluang kerja dibidang komputer juga akan semakin terbuka luas. Untuk itu kompetensi tentang cara perakitan dan perbaikan hardware maupun software komputer pada masyarakat khususnya masyarakat di Desa Pandau Jaya sangat diperlukan agar mereka nantinya dapat mengatasi sendiri permasalahan pada perangakat komputer. Tingkat ketercapaian dari kegiatan Pengabdian Kepada Masyarakat yang telah dilakukan di desa Pandau Jaya adalah: 1) warga masyarakat khususnya remaja di desa pandau jaya kecamatan Siak Hulu memiliki pengetahuan dan keterampilan tentang perakitan dasar pada komputer. 2)Memiliki pengetahuan dan keterampilan mengenai cara melakukan perbaikan pada komputer. 3) Dapat mengatasi gangguan jika terjadi permasalahan sederhana yang timbul sewaktu-waktu. 4) Memiliki pengetahuan dan keterampilan mengenai cara melakukan installasi sistem operasi windows beserta programprogram apliaksi..
\end{abstract}

Kata kunci: perakitan computer; perbaikan computer; installasi windows; teknologi informasi

\begin{abstract}
The objectives to be achieved in community service activities are, so that the participating communities can: 1). Having knowledge of how to basic assembly of computers, 2). Having knowledge about how to install a Windows operating system and its application programs, 3). Having knowledge about how to repair / boot booting on computer hardware or software. This community service is carried out based on our observation, that in Pandau Jaya Village, Siak Hulu District $80 \%$ of the community has no knowledge of assembly and maintenance on PC computers (personal computers) or laptops. With the development of technology, especially computers that are increasingly widespread, so as to provide employment opportunities in the field of computers will also be more wide open. For this reason, competence in how to assemble and repair computer hardware and software in the community, especially the people in Pandau Jaya Village, is highly needed so that they can later overcome the problems themselves on the computer equipment. The level of achievement of Community Service activities that have been carried out in Pandau Jaya village are: 1) community members, especially teenagers in Pandau Jaya village, Siak Hulu sub-district have knowledge and skills about basic assembly on computers. 2) Having knowledge and skills on how to make improvements to the computer. 3) Can overcome the interference if there are simple problems that arise at any time. 4) Having knowledge and skills on how to install an windows operating system along with application programs.
\end{abstract}

Keywords: computer assembly; computer repair; windows installation; information technology

To cite this article: Alfirman, Sukamto, G. Sastria, \& Z. Bahri. 2019. Perakitan dan perbaikan komputer untuk meningkatan kualitas remaja di Desa Pandau Jaya kecamatan Siak Hulu Kabupaten Kampar. Unri Conference Series: Community Engagement 1: 243-254 https://doi.org/10.31258/unricsce.1.243-254

(C) 2019 Authors

Peer-review under responsibility of the organizing committee of Seminar Nasional Pemberdayaan Masyarakat 2019 


\section{PENDAHULUAN}

Kegiatan Pengabdian Kepada Masyarakat merupakan salah satu bentuk kegiatan pengabdian kepada masyarakat oleh Perguruan Tinggi yang dilakukan oleh dosen dan dibantu mahasiswa di bawah bimbingan pimpinan Pemerintah Daerah. Melalui kegiatan ini dosen dapat mengaplikasikan ilmu pengetahuan serta keterampilan yang dimiliki, sekaligus dapat memperoleh pengalaman serta berkontribusi dalam upaya pembangunan Desa.

Pengabdian masyarakat dilaksanakan oleh dosen yang menerima hibah pengabdian masyarakat melalui dana DIPA Universitas Riau, yang wajib melibatkan mahasiswa dalam pelaksanaan pengabdian dalam bentuk Kukerta. Dalam kegiatan Pengabdian Kepada Masyarakat kali ini dilaksanakan dengan tema kegiatan "Perakitan dan Perbaikan Komputer Untuk Meningkatkan Kualitas Remaja di Desa Pandau Jaya Kecamatan Siak Hulu Kabupaten Kampar".

Dalam kegiatan Pengabdian Kepada Masyarakat kali ini dilaksanakan dengan tema kegiatan "Perakitan dan Perbaikan Komputer Untuk Meningkatkan Kualitas Remaja di Desa Pandau Jaya Kecamatan Siak Hulu Kabupaten Kampar". Desa Pandau Jaya memiliki luas \pm 14.274 Ha dengan jumlah penduduk 32.354 jiwa. Penduduk usia 7-18 tahun yang masih sekolah sebanyak 298 orang, Penduduk usia 18-56 tahun yang bekerja sebanyak 23.570 orang, dan penduduk usia 18-56 tahun yang belum / tidak bekerja sebanyak 1210 orang.

Di era globalisasi, Sumber Daya Manusia (SDM) merupakan salah satu elemen penting bagi suatu daerah (desa). Dimana tanpa adanya sumber daya manusia yang berkualitas baik, cita-cita untuk mewujudkan desa yang maju, mandiri dan sejahtera akan mustahil untuk terwujud. Desa Pandau Jaya memiliki potensi SDM terutama remaja yang cukup banyak. Keberadaan potensi ini tentunya harus mendapatkan perhatian khusus, mengingat remaja merupakan generasi penerus bangsa di masa yang akan datang.

Perkembangan Ilmu Pengetahuan dan Teknologi (IPTEK) menuntut manusia untuk memahami teknologi, terutama komputer. Komputer mengambil peranan penting dalam perkembangan teknologi. Komputer sendiri dewasa ini sudah menjadi kebutuhan dalam setiap lini kehidupan. Hampir seluruh sektor baik ekonomi, pendidikan, dan pemerintahan membutuhkan Komputer guna membuat kinerja lebih efektif dan efisien.

Dunia tengah bersiap menghadapi Revolusi Industri 4.0. Revolusi Industri 4.0 adalah transformasi komprehensif dari keseluruhan aspek produksi di Industri melalui penggabungan teknologi digital dan internet dengan industry konvensional. Revolusi Industri 4.0 sendiri akan membawa perubahan yang signifikan bagi kehidupan manusia. Akan banyak pekerjaan yang nantinya menghilang dan akan muncul pekerjaan-pekerjaan baru. Salah satu tantangan Indonesia dalam menghadapi Revolusi Industri 4.0 ialah kurangnya pengetahuan dan keterampilan masyarakat mengenai komputer dan internet. Maka dari itu keterampilan mengenai komputer baik hardware maupun software seharusnya sudah menjadi pengetahuan dasar bagi remaja di Indonesia guna menghadapi tantang Revolusi Industri 4.0.

Perakitan komputer penting untuk dipelajari karena dengan mengetahui dengan baik komponen-komponen yang ada komputer. Dengan kemudian akan mudah diketahui kerusakan dari komputer tersebut sehingga memudahkan dalam perbaikannya. Pengetahuan mengenai installasi software komputer juga penting untuk dimiliki. Tanpa adanya software tentunya komputer tidak akan dapat beroperasi.

Di Desa Pandau Jaya sendiri belum terdapat lembaga pelatihan komputer yang memberikan pelatihan komputer baik hardware maupun software secara gratis, dimana kerap ditemui para remaja kesulitan dalam mengoperasikan komputer. Ketidakmampuan dalam mengoperasikan komputer tentunya merupakan fenomena yang harus ditangani dengan serius. Tanpa adanya kemampuan mengenai teknologi terutama komputer, maka akan sulit bagi para remaja Desa Pandau Jaya menghadapi persaingan pada dunia global. Sehingga kemudian dirasa perlu untuk mengadakan suatu pelatihan perakitan komputer yang ditujukan bagi remaja Desa Pandau Jaya.

Pelatihan perakitan komputer juga diperlukan untuk meningkatkan taraf perekonomian di desa Pandau Jaya. Hal tersebut dikarenakan keahlian mengenai perakitan komputer dan installasi sistem operasi serta program utility sendiri merupakan suatu keahlian yang memiliki nilai ekonomi yang cukup tinggi. Dengan memiliki keterampilan mengenai perakitan komputer dan installasi software, remaja nantinya dapat menghasilkan pendapatan tambahan atau bahkan dapat menjadikannya sebagai peluang usaha yang nantinya dapat membuka lapangan pekerjaan bagi masyarakat desa Pandau Jaya. 


\section{MASALAH}

Berdasarkan paparan yang telah diuraikan pada pendahuluan tersebut, maka permasalahan yang akan dibahas adalah:

1. Apakah dengan pelatihan dapat meningkatkan pengetahuan dan keterampilan tentang perakitan dasar dan perbaikan komputer warga masyarakat, khususnya remaja di desa Pandau Jaya kecamatan Siak Hulu?

2. Apakah dengan pelatihan dapat meningkatkan pengetahuan dan keterampilan warga masyarakat khususnya remaja di desa Pandau Jaya kecamatan Siak Hulu tentang perbaikan / trobleshooting pada komputer?

3. Apakah dengan pelatihan dapat meningkatkan pengetahuan dan keterampilan warga masyarakat khususnya remaja di desa Pandau Jaya kecamatan Siak Hulu tentang installasi sistem operasi dan program-program aplikasi pada komputer?

\section{METODE}

Metode yang digunakan dalam pelaksanaan kegiatan Pengabdian Kepada Masyarakat yang diselenggarakan di Desa Pandau Jaya diantaranya sebagai berikut:

\section{a. Pengenalan}

Kegiatan Pengabdian Kepada Masyarakat dilaksanakan berdasarkan pada suatu tema dan program yang merupakan gagasan bersama tim dan Mahasiswa. Diawali dengan pengenalan komponen-komponen (hardware) yang terdapat didalam komputer, pengenalan langkah-langkah merakit komputer PC, pengenalan langkah-langkah installasi sistem operasi windows, langkah-langkah installasi program aplikasi utility yang dilaksanakan dengan metode sosialisasi dan pemaparan dari narasumber.

\section{b. Praktik}

Pada metode praktik, peserta yang didampingi oleh tim Pengabdian Kepada Masyarakat melaksanakan praktik perakitan komputer, praktik installasi system operasi windows, praktik installasi program aplikasi secara mandiri. Kegiatan ini dilaksanakan dengan metode demonstrasi dari narasumber dan langsung dipraktikkan oleh peserta (Azwanti et al., 2019).

\section{c. Evaluasi}

Kegiatan evaluasi tidak bisa ditinggalkan dalam setiap kegiatan, dengan mtode evaluasi ini kita bisa mengetahui beberapa aspek yang kurang atau kelemahan-kelemahan dalam kegiatan ini. Dalam metode pengevaluasian, Tim Pengabdian Kepada Masyarakat memberikan penilaian atas pengetahuan peserta sebagaimana yang telah dijelaskan oleh Tim Pengabdian Kepada Masyarakat sebelumnya.

\section{PEMBAHASAN}

Pelaksanaan Pengabdian Kepada Masyarakat 2019 yang dimulai pada tanggal 2 Mei 2019 sampai dengan 31 mei 2019. Yang mana pelaksanaannya dilakukan oleh tim dosen, dan dibantu oleh mahasiswa KUKERTA dan dihadiri oleh masyarakat Desa Pandau Jaya.

\section{a. Rincian program Pengabdian Kepada Masyarakat}

Pelaksanaan program Pengabdian Kepada Masyarakat dilaksanakan di tiga tempat yaitu di aula kantor Desa Pandau Jaya kemudian di Panti Asuhan YLBMI dan terakhir di SMP 04 Pandau Jaya. Beberapa program kegiatan Pengabdian Kepada Masyarakat dapat diuraikan pada Tabel 1 sampai dengan Tabel 14.

Tabel 1. Pengenalan Hardware pada Komputer PC

\begin{tabular}{ll}
\hline \multicolumn{1}{c}{ Nama Kegiatan } & \multicolumn{1}{c}{ Pengenalan hardware pada Komputer PC. } \\
\hline Tujuan & $\begin{array}{l}\text { Peserta mengetahui mengenai komponen-komponen hardware pada komputer PC. } \\
\text { Menambah wawasan dan pengetahuan mengenai komponen-komponen hardware } \\
\text { Manfaat }\end{array}$ \\
\hline
\end{tabular}




\begin{tabular}{|c|c|}
\hline Nama Kegiatan & Pengenalan hardware pada Komputer PC. \\
\hline $\begin{array}{l}\text { Waktu dan Tempat } \\
\text { Pelaksanaan }\end{array}$ & Aula Kantor Desa Pandau pada 2/5/2019, Aula Panti Asuhan YLBMI pada 3/5/2019. \\
\hline Jumlah Peserta & $\begin{array}{l}\text { Aula Kantor Desa Pandau Jaya sebanyak } 25 \text { peserta, Aula Panti Asuhan YLBMI } \\
\text { sebanyak } 25 \text { peserta }\end{array}$ \\
\hline Sambutan Peserta & Antusias \\
\hline Hambatan & $\begin{array}{l}\text { Acara dimulai tidak sesuai dengan waktu yang telah ditentukan karena peserta } \\
\text { pelatihan yang telat hadir ke ruangan. }\end{array}$ \\
\hline Nilai & $\begin{array}{l}\text { Seluruh peserta mendapatkan nilai lebih dari } 85 \text {, berikut peserta sudah mengerti akan } \\
\text { materi yang diberikan }\end{array}$ \\
\hline Peran Mahasiswa & Pelaksana dan fasilitator \\
\hline Peran Masyarakat & Peserta pelatihan \\
\hline Pelaksana & Tim Pengabdian Kepada Masyarakat, Masyarakat Desa Pandau Jaya \\
\hline
\end{tabular}

Tabel 2. Langkah-langkah merakit komputer PC

\begin{tabular}{|c|c|}
\hline Nama Kegiatan & Langkah-langkah merakit komputer PC. \\
\hline Tujuan & Peserta dapat mengetahui cara merakit komputer PC dengan benar. \\
\hline Manfaat & $\begin{array}{l}\text { Menambah wawasan dan pengetahuan mengenai langkah-langkah dari merakit } \\
\text { komputer. }\end{array}$ \\
\hline $\begin{array}{l}\text { Waktu dan Tempat } \\
\text { Pelaksanaan }\end{array}$ & $\begin{array}{l}\text { Aula Kantor Desa Pandau pada 4/5/2019, Aula Panti Asuhan YLBMI pada Kamis } \\
5 / 5 / 2019 \text {. }\end{array}$ \\
\hline jumlah Peserta & $\begin{array}{l}\text { Aula Kantor Desa Pandau Jaya sebanyak } 25 \text { peserta, Aula Panti Asuhan YLBMI } \\
\text { sebanyak } 25 \text { peserta. }\end{array}$ \\
\hline Sambutan Peserta & Antusias \\
\hline Hambatan & $\begin{array}{l}\text { Acara dimulai tidak sesuai dengan waktu yang telah ditentukan karena peserta } \\
\text { pelatihan yang telat hadir ke ruangan. }\end{array}$ \\
\hline Nilai & $\begin{array}{l}\text { Seluruh peserta mendapatkan nilai lebih dari } 85 \text {, berikut peserta sudah mengerti akan } \\
\text { materi yang diberikan. }\end{array}$ \\
\hline Peran Mahasiswa & Pelaksana dan fasilitator. \\
\hline Peran Masyarakat & Peserta pelatihan. \\
\hline Pelaksana & Tim Pengabdian Kepada Masyarakat, Masyarakat Desa Pandau jaya \\
\hline
\end{tabular}

Tabel 3. Praktek merakit komputer PC

\begin{tabular}{|c|c|}
\hline Nama Kegiatan & Langkah-langkah merakit komputer PC. \\
\hline Tujuan & Peserta dapat mengetahui cara merakit komputer PC dengan benar. \\
\hline Manfaat & Menambah wawasan dan pengetahuan mengenai merakit komputer. \\
\hline $\begin{array}{l}\text { Waktu dan Tempat } \\
\text { Pelaksanaan }\end{array}$ & Aula Kantor Desa Pandau pada 6/5/2019, Aula Panti Asuhan YLBMI pada 7/5/2019. \\
\hline jumlah Peserta & $\begin{array}{l}\text { Aula Kantor Desa Pandau Jaya sebanyak } 25 \text { peserta, Aula Panti Asuhan YLBMI } \\
\text { sebanyak } 25 \text { peserta. }\end{array}$ \\
\hline Sambutan Peserta & Antusias. \\
\hline Hambatan & $\begin{array}{l}\text { Acara dimulai tidak sesuai dengan waktu yang telah ditentukan karena peserta } \\
\text { pelatihan yang telat hadir ke ruangan. }\end{array}$ \\
\hline
\end{tabular}




\begin{tabular}{ll}
\hline \multicolumn{1}{c}{ Nama Kegiatan } & \multicolumn{1}{c}{ Langkah-langkah merakit komputer PC. } \\
\hline Nilai & $\begin{array}{l}\text { Seluruh peserta mendapatkan nilai lebih dari 85, berikut peserta sudah mengerti akan } \\
\text { materi yang diberikan. } \\
\text { Peran Mahasiswa }\end{array}$ \\
Pelaksana dan fasilitator. \\
Peran Masyarakat & Peserta pelatihan. \\
Pelaksana & Tim Pengabdian Kepada Masyarakat, Masyarakat Desa Pandau jaya \\
\hline
\end{tabular}

Tabel 4. Evaluasi kemampuan peserta mengenai komponen-komponen hardware pada komputer PC

\begin{tabular}{ll}
\hline \multicolumn{1}{c}{ Nama Kegiatan } & \multicolumn{1}{c}{ Evaluasi kemampuan peserta mengenai komponen-komponen hardware pada } \\
komputer PC \\
\hline Tujuan & Mengetahui kemampuan peserta mengenai komponen hardware pada komputer PC. \\
Manfaat & $\begin{array}{l}\text { Menambah wawasan dan pengetahuan mengenai komponen-komponen hardware } \\
\text { pada komputer PC. }\end{array}$ \\
Waktu dan Tempat & Aula Kantor Desa Pandau Jaya pada 8/5/2019 \\
Pelaksanaan & 24 peserta \\
jumlah Peserta & Antusias \\
Sambutan Peserta & Peserta pelatihan yang hadir terus berkurang dari setelah pertemuan pertama . \\
Hambatan & $\begin{array}{l}\text { Seluruh peserta mendapatkan nilai lebih dari 85, berikut peserta sudah mengerti akan } \\
\text { materi yang diberikan }\end{array}$ \\
Nilai & $\begin{array}{l}\text { Pelaksana dan fasilitator. } \\
\text { Peran Mahasiswa }\end{array}$ \\
Peran Masyarakat & $\begin{array}{l}\text { Peserta pelatihan. } \\
\text { Pelaksana }\end{array}$
\end{tabular}

Tabel 5. Evaluasi kemampuan peserta mengenai perakitan komputer PC

\begin{tabular}{ll}
\hline \multicolumn{1}{c}{ Nama Kegiatan } & \multicolumn{1}{c}{ Evaluasi kemampuan peserta perakitan komputer PC } \\
\hline Tujuan & Mengetahui kemampuan peserta mengenai perakitan pada komputer PC. \\
Manfaat & Menambah wawasan dan pengetahuan serta dapat membuka jasa merakit komputer. \\
Waktu dan Tempat & Aula Kantor Desa Pandau Jaya pada hari jumat tanggal 9/5/2019, Panti Asuhan \\
Pelaksanaan & YLBMI pada 10/5/2019. \\
jumlah Peserta & Aula Kantor Desa 23 peserta, Panti Asuhan 22 peserta. \\
Sambutan Peserta & Antusias \\
Hambatan & $\begin{array}{l}\text { Peserta pelatihan yang hadir terus berkurang dari setelah pertemuan pertama dan laptop } \\
\text { yang tersedia tidak mencukupi dengan jumlah peserta pelatihan yang hadir. }\end{array}$ \\
Nilai & Seluruh peserta mendapatkan nilai lebih dari 85, berikut peserta sudah mengerti akan \\
Peran Mahasiswa & Pelaksana dan fasilitator. \\
Peran Masyarakat & Peserta pelatihan. \\
pelaksana & Tim Pengabdian Kepada Masyarakat, Masyarakat Desa Pandau jaya \\
\hline
\end{tabular}


Tabel 6. Penjelasan permasalahan dan solusi pada perangkat keras komputer

\begin{tabular}{|c|c|}
\hline Nama Kegiatan & Penjelasan permasalahan dan solusi pada perangkat keras komputer. \\
\hline Tujuan & Peserta mengetahui permasalahan dan cara mengatasinya. \\
\hline manfaat & $\begin{array}{l}\text { Menambah wawasan dan pengetahuan mengenai permasalahan dan solusi pada } \\
\text { perangkat komputer. }\end{array}$ \\
\hline $\begin{array}{l}\text { Waktu dan Tempat } \\
\text { Pelaksanaan }\end{array}$ & $\begin{array}{l}\text { Aula Kantor Desa Pandau Jaya pada tanggal 12/5/2019, Panti Asuhan YLBMI pada } \\
11 / 5 / 2019 \text {. }\end{array}$ \\
\hline jumlah Peserta & 22 orang peserta \\
\hline Sambutan Peserta & Antusias \\
\hline hambatan & $\begin{array}{l}\text { Peserta pelatihan yang hadir terus berkurang dari setelah pertemuan pertama dan laptop } \\
\text { yang tersedia tidak mencukupi dengan jumlah peserta pelatihan yang hadir. }\end{array}$ \\
\hline Nilai & $\begin{array}{l}\text { Seluruh peserta mendapatkan nilai lebih dari } 85 \text {, berikut peserta sudah mengerti akan } \\
\text { materi yang diberikan. }\end{array}$ \\
\hline Peran Mahasiswa & Pelaksana dan fasilitator. \\
\hline Peran Masyarakat & Peserta pelatihan. \\
\hline pelaksana & Tim Pengabdian Kepada Masyarakat, Masyarakat Desa Pandau jaya \\
\hline
\end{tabular}

Tabel 7. Langkah-Langkah melakukan installasi sistem operasi windows

\begin{tabular}{|c|c|}
\hline Nama Kegiatan & Langkah-Langkah melakukan installasi sistem operasi windows \\
\hline Tujuan & Peserta mengetahui cara installasi sistem operasi windows. \\
\hline manfaat & $\begin{array}{l}\text { Menambah wawasan dan pengetahuan mengenai langkah-langkah melakukan } \\
\text { installasi sistem opersi windows. }\end{array}$ \\
\hline $\begin{array}{l}\text { Waktu dan Tempat } \\
\text { Pelaksanaan }\end{array}$ & $\begin{array}{l}\text { Aula Kantor Desa Pandau Jaya pada 13/5/2019, Panti Asuhan YLBMI pada } \\
\text { 14/5/2019, SMP Negeri } 4 \text { Siak Hulu pada 15/5/2019. }\end{array}$ \\
\hline jumlah Peserta & $\begin{array}{l}\text { Aula Kantor Desa Pandau Jaya sebanyak } 20 \text { peserta, Panti Asuhan YLBMI sebanyak } \\
20 \text { peserta, SMP Negeri } 4 \text { Siak Hulu sebanyak } 30 \text { peserta }\end{array}$ \\
\hline Sambutan Peserta & Antusias \\
\hline hambatan & $\begin{array}{l}\text { Peserta pelatihan yang hadir terus berkurang dari setelah pertemuan pertama dan } \\
\text { laptop yang tersedia tidak mencukupi dengan jumlah peserta pelatihan yang hadir }\end{array}$ \\
\hline Nilai & $\begin{array}{l}\text { Seluruh peserta mendapatkan nilai lebih dari } 85 \text {, berikut peserta sudah mengerti akan } \\
\text { materi yang diberikan }\end{array}$ \\
\hline Peran Mahasiswa & Pelaksana dan fasilitator \\
\hline Peran Masyarakat & Peserta pelatihan \\
\hline pelaksana & Tim Pengabdian Kepada Masyarakat, Masyarakat Desa Pandau jaya \\
\hline
\end{tabular}

Tabel 8. Praktik installasi sistem operasi windows

\begin{tabular}{ll}
\hline \multicolumn{1}{c}{ Nama Kegiatan } & \multicolumn{1}{c}{ Praktik installasi sistem operasi windows } \\
\hline Tujuan & Peserta mengetahui cara installasi sistem operasi windows (secara langsung). \\
manfaat & Menambah wawasan dan pengetahuan mengenai installasi sistem operasi windows. \\
Waktu dan Tempat & Aula Kantor Desa Pandau Jaya pada 16/5/2019, Panti Asuhan YLBMI pada 17/5/2019, \\
Pelaksanaan & SMP Negeri 4 Siak Hulu pada 18/5/2019. \\
jumlah Peserta & Aula Kantor Desa Pandau Jaya sebanyak 20 peserta, Panti Asuhan YLBMI sebanyak \\
& 20 peserta, SMP Negeri 4 Siak Hulu sebanyak 30 peserta \\
\hline
\end{tabular}




\begin{tabular}{ll}
\hline \multicolumn{1}{c}{ Nama Kegiatan } & \multicolumn{1}{c}{ Praktik installasi sistem operasi windows } \\
\hline Sambutan Peserta & $\begin{array}{l}\text { Antusias } \\
\text { Peserta pelatihan yang hadir terus berkurang dari setelah pertemuan pertama dan laptop } \\
\text { hambatan }\end{array}$ \\
Nilai & $\begin{array}{l}\text { Seluruh peserta mendapatkan nilai lebih dari 85, berikut peserta sudah mengerti akan } \\
\text { materi yang diberikan. }\end{array}$ \\
Peran Mahasiswa & $\begin{array}{l}\text { Pelaksana dan fasilitator. } \\
\text { Peran Masyarakat }\end{array}$ \\
pelaksana & $\begin{array}{l}\text { Peserta pelatihan. } \\
\text { Tim Pengabdian Kepada Masyarakat, Masyarakat Desa Pandau jaya }\end{array}$ \\
\hline
\end{tabular}

Tabel 9. Penjelasan permasalahan yang sering terjadi dalam installasi sistem operasi windows

\begin{tabular}{|c|c|}
\hline Nama Kegiatan & Penjelasan permasalahan yang sering terjadi dalam installasi sistem operasi windows \\
\hline Tujuan & $\begin{array}{l}\text { Peserta mengetahui permasalahan dalam installasi sistem operasi windows dan cara } \\
\text { mengatasinya. }\end{array}$ \\
\hline Manfaat & $\begin{array}{l}\text { Menambah wawasan dan pengetahuan mengenai permasalahan yang sering terjadi } \\
\text { dalam installasi sistem operasi windows. }\end{array}$ \\
\hline $\begin{array}{l}\text { Waktu dan Tempat } \\
\text { Pelaksanaan }\end{array}$ & $\begin{array}{l}\text { Aula Kantor Desa Pandau Jaya pada 20/6/2019, Panti Asuhan YLBMI pada 19/5/2019, } \\
\text { SMP Negeri } 4 \text { Siak Hulu pada 21/5/2019. }\end{array}$ \\
\hline jumlah Peserta & $\begin{array}{l}\text { Aula Kantor Desa Pandau Jaya sebanyak } 20 \text { peserta, Panti Asuhan YLBMI sebanyak } \\
20 \text { peserta, SMP Negeri } 4 \text { Siak Hulu sebanyak } 30 \text { peserta }\end{array}$ \\
\hline Sambutan Peserta & Antusias \\
\hline Hambatan & $\begin{array}{l}\text { Peserta pelatihan yang hadir terus berkurang dari setelah pertemuan pertama dan laptop } \\
\text { yang tersedia tidak mencukupi dengan jumlah peserta pelatihan yang hadir. }\end{array}$ \\
\hline Nilai & $\begin{array}{l}\text { Seluruh peserta mendapatkan nilai lebih dari } 85 \text {, berikut peserta sudah mengerti akan } \\
\text { materi yang diberikan. }\end{array}$ \\
\hline Peran Mahasiswa & Pelaksana dan fasilitator. \\
\hline Peran Masyarakat & Peserta pelatihan. \\
\hline pelaksana & Tim Pengabdian Kepada Masyarakat, Masyarakat Desa Pandau jaya \\
\hline
\end{tabular}

Tabel 10. Evaluasi kemampuan peserta mengenai langkah-langkah installasi sistem operasi windows

\begin{tabular}{ll}
\hline \multicolumn{1}{c}{ Nama Kegiatan } & \multicolumn{1}{c}{$\begin{array}{c}\text { Evaluasi kemampuan peserta mengenai langkah-langkah installasi sistem operasi } \\
\text { windows }\end{array}$} \\
\hline Tujuan & $\begin{array}{l}\text { Mengetahui kemampuan peserta mengenai cara installasi sistem operasi windows } \\
\text { Menambah wawasan dan pengetahuan mengenai installasi sistem operasi windows dan } \\
\text { Manfaat }\end{array}$ \\
Waktu dan Tempat membuka jasa installasi program komputer \\
Pelaksanaan & $\begin{array}{l}\text { Aula Kantor Desa Pandau Jaya pada Sabtu 22/6/2019, Panti Asuhan YLBMI pada } \\
\text { Kamis 23/5/2019, SMP Negeri 4 Siak Hulu pada 24/5/2019 }\end{array}$ \\
jumlah Peserta & $\begin{array}{l}\text { Aula Kantor Desa Pandau Jaya sebanyak 20 peserta, Panti Asuhan YLBMI sebanyak } \\
\text { 20 peserta, SMP Negeri 4 Siak Hulu sebanyak 30 peserta }\end{array}$ \\
Sambutan Peserta & $\begin{array}{l}\text { Antusias } \\
\text { Peserta pelatihan yang hadir terus berkurang dari setelah pertemuan pertama dan laptop } \\
\text { Hambatan }\end{array}$ \\
yilai & $\begin{array}{l}\text { Seluruh peserta mendapatkan nilai lebih dari 85, berikut peserta sudah mengerti akan } \\
\text { materi yang diberikan. }\end{array}$ \\
\hline
\end{tabular}




\begin{tabular}{ll}
\hline Peran Mahasiswa & Pelaksana dan fasilitator. \\
Peran Masyarakat & Peserta pelatihan. \\
Pelaksana & Tim Pengabdian Kepada Masyarakat, Masyarakat Desa Pandau jaya \\
\hline
\end{tabular}

Tabel 11. Pengenalan Langkah-langkah installasi program aplikasi

\begin{tabular}{|c|c|}
\hline Nama Kegiatan & Pengenalan Langkah-langkah installasi program aplikasi. \\
\hline Tujuan & Peserta mengetahui langkah-langkah installasi program aplikasi. \\
\hline Manfaat & $\begin{array}{l}\text { Menambah wawasan dan pengetahuan mengenai langkah-langkah installasi program } \\
\text { aplikasi. }\end{array}$ \\
\hline $\begin{array}{l}\text { Waktu dan Tempat } \\
\text { Pelaksanaan }\end{array}$ & $\begin{array}{l}\text { Panti Asuhan YLBMI pada Jumat 25/5/2019, SMP Negeri } 4 \text { Siak Hulu pada Kamis } \\
\text { 26/5/2019. }\end{array}$ \\
\hline jumlah Peserta & $\begin{array}{l}\text { Panti Asuhan YLBMI sebanyak } 8 \text { peserta, SMP Negeri } 4 \text { Siak Hulu sebanyak } 30 \\
\text { peserta. }\end{array}$ \\
\hline Sambutan Peserta & Antusias \\
\hline hambatan & laptop yang tersedia tidak mencukupi dengan jumlah peserta pelatihan yang tersedia. \\
\hline Nilai & $\begin{array}{l}\text { Seluruh peserta mendapatkan nilai lebih dari } 85 \text {, berikut peserta sudah mengerti akan } \\
\text { materi yang diberikan. }\end{array}$ \\
\hline Peran Mahasiswa & Pelaksana dan fasilitator. \\
\hline Peran Masyarakat & Peserta pelatihan. \\
\hline pelaksana & Tim Pengabdian Kepada Masyarakat, Masyarakat Desa Pandau jaya \\
\hline
\end{tabular}

Tabel 12. Praktik langkah-langkah installasi program aplikasi

\begin{tabular}{ll}
\hline \multicolumn{1}{c}{ Nama Kegiatan } & \multicolumn{1}{c}{ Praktik langkah-langkah installasi program aplikasi. } \\
\hline Tujuan & Peserta mengetahui cara installasi program aplikasi \\
Manfaat & Menambah wawasan dan pengetahuan mengenai installasi program aplikasi \\
Waktu dan Tempat & Panti Asuhan YLBMI pada Jumat 27/5/2019, SMP Negeri 4 Siak Hulu pada 28/5/2019 \\
Pelaksanaan & Panti Asuhan YLBMI sebanyak 8 peserta, SMP Negeri 4 Siak Hulu sebanyak 30 \\
jumlah Peserta & peserta \\
Sambutan Peserta & Antusias \\
Hambatan & Laptop yang tersedia tidak mencukupi dengan jumlah peserta pelatihan yang tersedia. \\
Nilai & Seluruh peserta mendapatkan nilai lebih dari 85, berikut peserta sudah mengerti akan \\
Peran Mahasiswa & materi yang diberikan \\
Peran Masyarakat & Peserta pelatihan \\
pelaksana & Tim Pengabdian Kepada Masyarakat, Masyarakat Desa Pandau jaya \\
\hline
\end{tabular}


Tabel 13. Penjelasan fungsi dan pegunaan dari program-program aplikasi utility

\begin{tabular}{|c|c|}
\hline Nama Kegiatan & Penjelasan fungsi dan pegunaan dari program-program aplikasi utility. \\
\hline Tujuan & Peserta mengetahui fungsi dan kegunaan dari program-program aplikasi utility. \\
\hline Manfaat & $\begin{array}{l}\text { Menambah wawasan dan pengetahuan mengenai fungsi dan penggunaan dari program- } \\
\text { program aplikasi utility. }\end{array}$ \\
\hline $\begin{array}{l}\text { Waktu dan Tempat } \\
\text { Pelaksanaan }\end{array}$ & Panti Asuhan YLBMI pada 29/5/2019, SMP Negeri 4 Siak Hulu pada 29/5/2019 \\
\hline jumlah Peserta & $\begin{array}{l}\text { Panti Asuhan YLBMI sebanyak } 8 \text { peserta, SMP Negeri } 4 \text { Siak Hulu sebanyak } 30 \\
\text { peserta. }\end{array}$ \\
\hline Sambutan Peserta & Antusias \\
\hline Hambatan & Laptop yang tersedia tidak mencukupi dengan jumlah peserta pelatihan yang tersedia. \\
\hline Nilai & $\begin{array}{l}\text { Seluruh peserta mendapatkan nilai lebih dari } 85 \text {, berikut peserta sudah mengerti akan } \\
\text { materi yang diberikan. }\end{array}$ \\
\hline Peran Mahasiswa & Pelaksana dan fasilitator. \\
\hline Peran Masyarakat & Peserta pelatihan. \\
\hline Pelaksana & Tim Pengabdian Kepada Masyarakat, Masyarakat Desa Pandau jaya \\
\hline
\end{tabular}

Tabel 14. Evaluasi kemampuan peserta dalam installasi dan penggunaan program aplikasi utility

\begin{tabular}{ll}
\hline \multicolumn{1}{c}{ Nama Kegiatan } & \multicolumn{1}{c}{ Evaluasi kemampuan peserta dalam installasi dan penggunaan program aplikasi } \\
utility
\end{tabular}

\section{b. Dokumentasi kegiatan Pengabdian Kepada Masyarakat}

Kegiatan Pengabdian Kepada Masyarakat yang telah dilaksanakan oleh tim dosen pengabdian dan mahasiswa KUKERTA di tiga tempat yaitu di aula kantor Desa Pandau Jaya kemudian di Panti Asuhan YLBMI dan terakhir di SMP 04 Pandau Jaya. Berikut ini adalah dokumentasi kegiatan-kegiatan yang telah dilaksanakan, dapat dilihat pada pada Gambar 1 sampai dengan Gambar 5 berikut ini: 


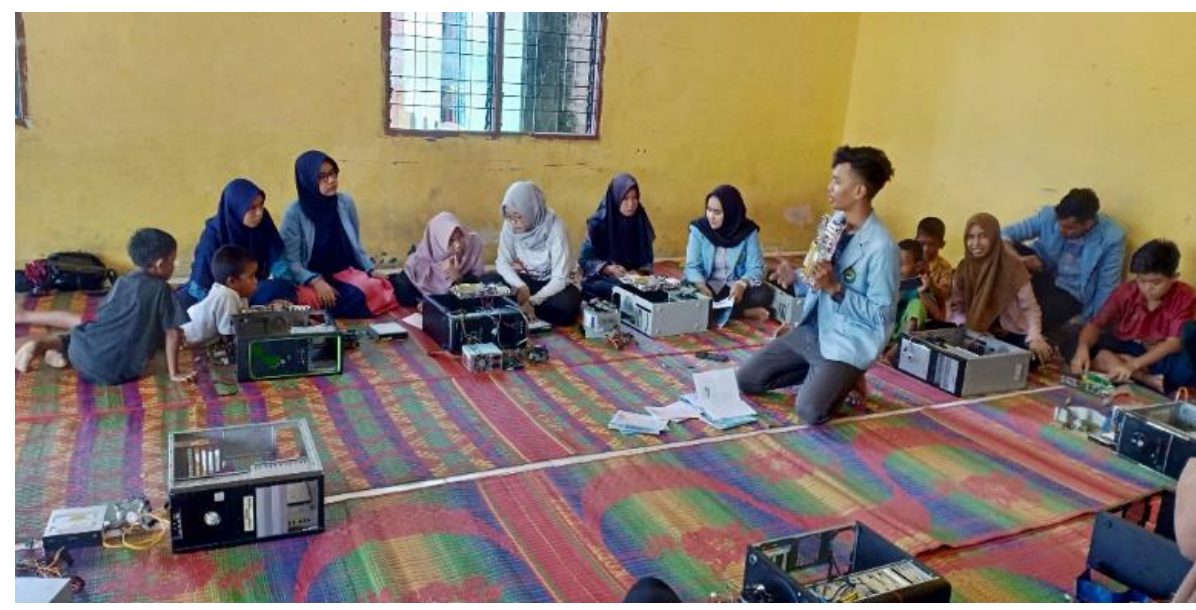

Gambar 1. Mahasiswa KUKERTA bersama tim Pengabdian Kepada Masyarakat menjelaskan mengenai perangkat keras komputer di panti Asuhan YBLMI

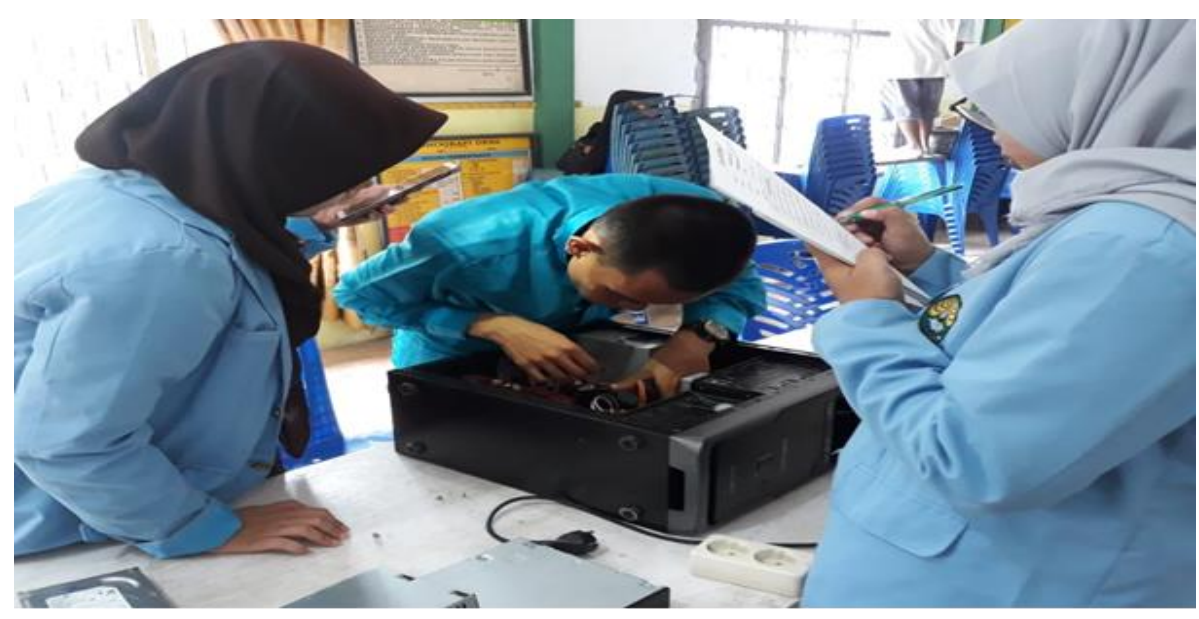

Gambar 2. Mahasiswa memberikan pengarahan tentang pengenalan dan perakitan komputer PC

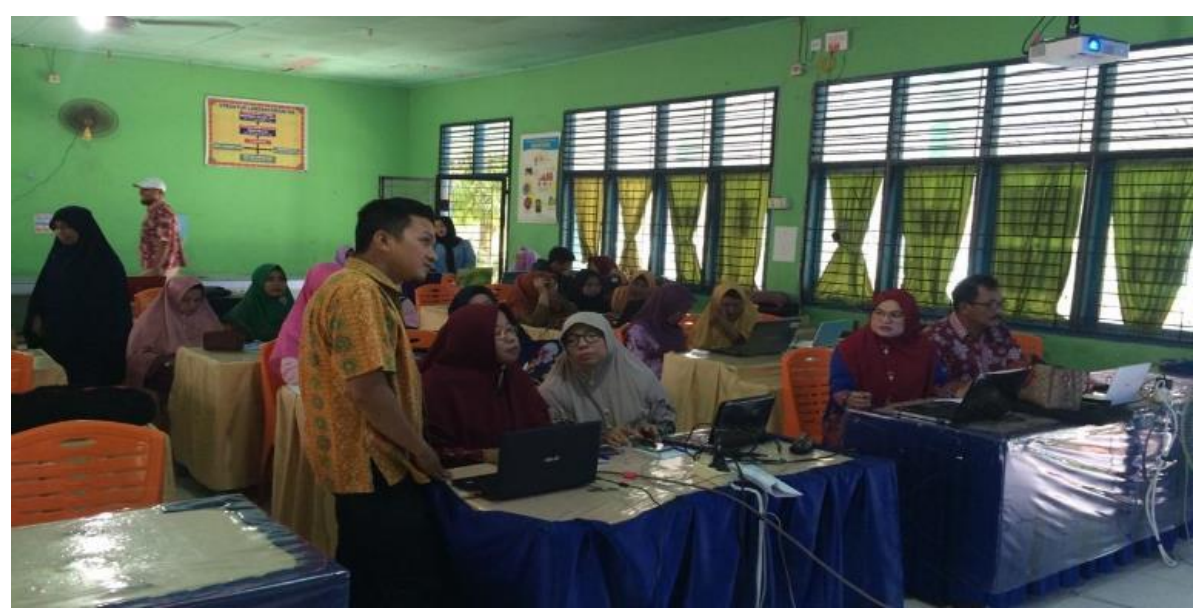

Gambar 3. Dosen Pembimbing menjelaskan langkah-langkah menginstall Windows dan program aplikasi di SMPN 04 Siak Hulu 


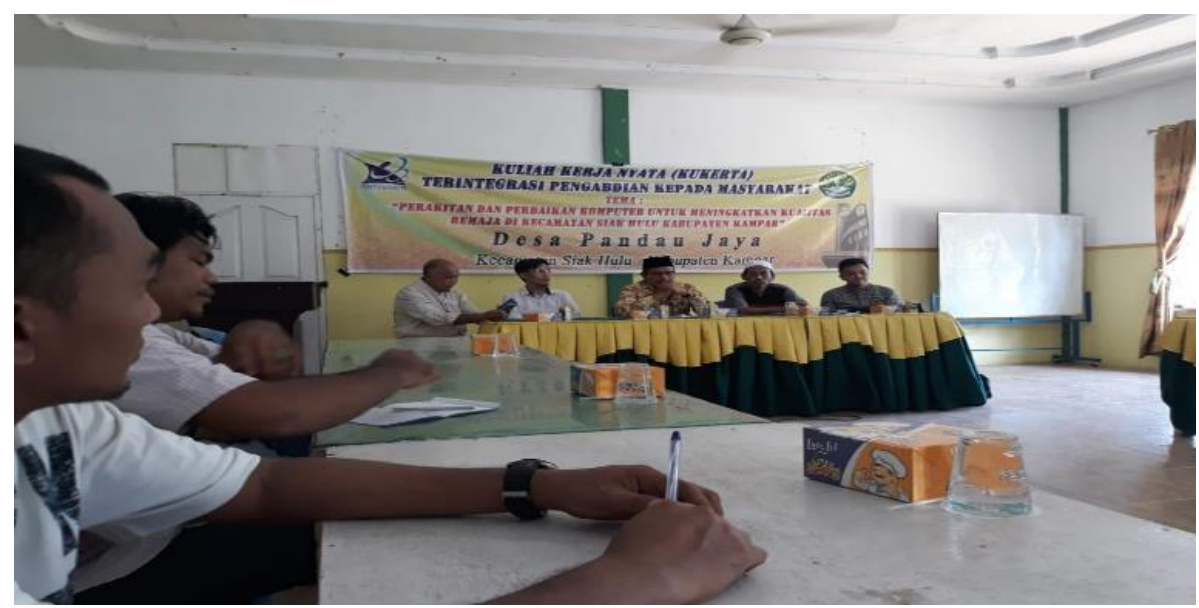

Gambar 4. Acara Pembukaan yang disampaikan oleh Kepala Desa Pandau Jaya

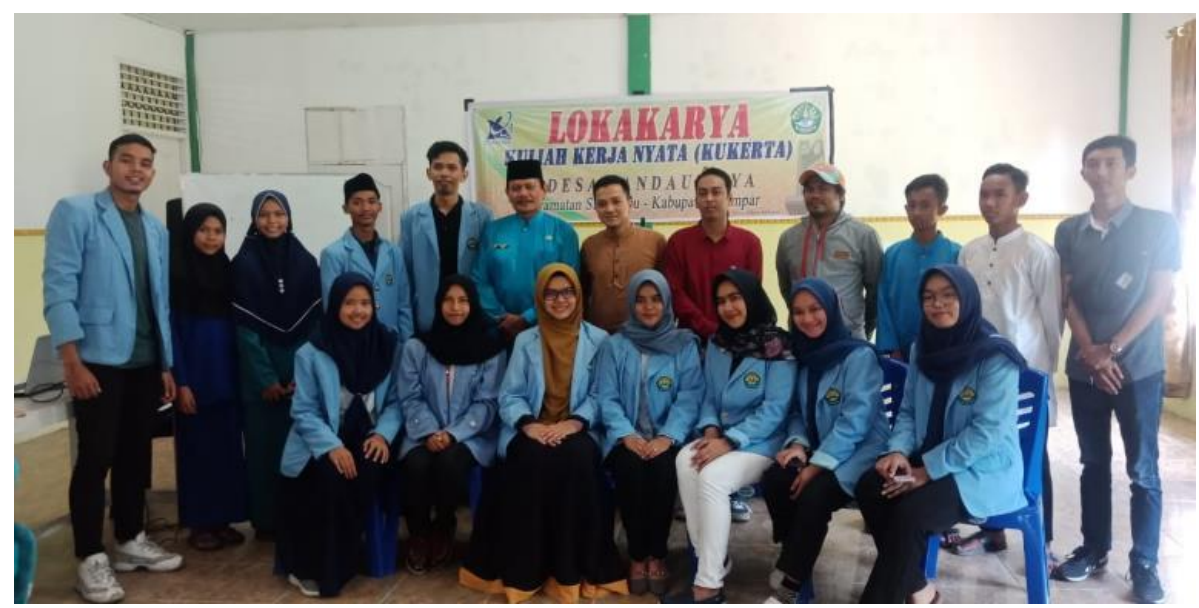

Gambar 5. Foto Bersama dengan Bapak Kades Desa Pandau Jaya Firdaus Roza dalam acara Lokakarya

\section{KESIMPULAN}

Kegiatan Pengabdian Kepada Masyarakat merupakan wahana bagi mahasiswa untuk mendukung terwujudnya sumber daya manusia yang berkualitas yang merupakan modal utama dalam pembangunan yang harus ditingkatkan agar mempunyai daya saing yang tinggi. Kegiatan Pengabdian Kepada masyarakat ini bertujuan memberikan pengalaman belajar bagi para peserta kegiatan mahasiswa dan kelompok sasaran Pengabdian Kepada Masyarakat untuk mengembangkan potensi diri, menyusun perencanaan, pengembangan dan peningkatan kualitas masyarakat.

Berdasarkan uraian pelaksanaan kegiatan Pengabdian Kepada Masyarakat di Desa Pandau Jaya, Kecamatan Siak Hulu, Kabupaten Kampar dari tanggal 2 Mei 2019 hingga 31 Mei 2019 dapat diperoleh kesimpulan sebagai berikut:

1. Kegiatan Pengabdian Kepada Masyarakat dengan sasaran Desa Pandau Jaya hampir keseluruhannya berjalan dengan baik dan lancar sesuai apa yang direncanakan dalam rancangan program dan kegiatan sebelum pelaksanaan. Meski target waktu yang direncanakan dalam rancangan rencana program dan kegiatan tidak dapat sepenuhnya dilaksanakan tepat waktu, namun dengan hal tersebut tidak merubah esensi pelaksanaan program dan kegiatan tersebut.

2. Kegiatan Pengabdian Kepada Masyarakat mengenai "Perakitan dan Perbaikan Komputer untuk Meningkatkan Kualitas Remaja di Desa Pandau Jaya" mendapatkan respon positif dan antusias dari para peserta di Kantor Desa Pandau Jaya, Panti Asuhan YLBMI dan SMP Neger 4 Siak Hulu. Walaupun memiliki beberapa hambatan namun dapat diatasi dengan baik.

3. Dari hasil evaluasi yang telah dilakukan oleh tim Pengabdian Kepada Masyarakat beserta mahasiswa KUKERTA, dengan cara dilakukan tes praktek perakitan komputer PC, installasi windows, installasi 
program aplikasi berserta trobleshooting, maka diambil kesimpulan bahwa 85\% peserta telah berhasil karena mencapai seluruh tujuan kegiatan dan program kerja yang telah diberikan dalam pelatihan tersebut.

\section{DAFTAR PUSTAKA}

Azwanti, N., A. Fajrin, \& Y. Mardiansyah. 2019. Pelatihan penggunaan aplikasi Paint dan pembuatan blog untuk meningkatkan kreatifitas pendidik pada HIMPAUDI Batam Center. Riau Journal of Empowerment 2(1): 9-13. https://doi.org/10.31258/raje.2.1.14

Perdana, A. 2013. Pengaruh Pelaksanaan Kuliah Kerja Nyata (KKN) Terhadap Keterampilan Sosial Mahasiswa Program Studi PPKN Universitas Lampung Tahun 2013. Jurnal Kultur Demokrasi 7(1): 6.

Prasetyo, H., dan W. Sutopo. 2018. Industri 4.0: Telaah Klasifikasi Aspek dan Arah Perkembangan Riset. Jurnal Teknik Industri 13(1): 19.

Salisma. 2019. Kukerta Terintegrasi, Pesantren YLBMI, Desa Pandau Jaya 2019, Universitas Riau. https://www.salisma.com/24066/kukerta-terintegrasi-pesantren-ylbmi-desa-pandau-jaya-2019-universitas-riau. Diakses pada 30 Juni 2019.

Salisma. 2019. Mahasiswa Kukerta Terintegrasi Universitas Riau, Sukses Gelar Lokakarya. https://www.salisma.com/24268/mahasiswa-kukerta-terintegrasi-universitas-riau-sukses-gelar-lokakarya Diakses pada 30 Juni 2019. 